Науковий вісник НлТУ України Scientific Bulletin of UNFU

https://nv.nltu.edu.ua

https://doi.org/10.36930/40300506

Article received $03.11 .2020 \mathrm{p}$.

Article accepted $12.10 .2020 \mathrm{p}$.

UDC 630.5:251.1[477]
ISSN 1994-7836 (print)

ISSN 2519-2477 (online)

$@ \bowtie$ Correspondence author

S. A. Sytnyk

sytnyk.s.a@dsau.dp.ua

Л. В. Мурадян ${ }^{1}$, С. А. Ситник ${ }^{2}$

${ }^{I}$ Дніпровський держсавний аграрно-економічний університет, м. Дніпро, Україна

${ }^{2}$ Національний університет біоресурсів і природокористування Украйни, м. Київ, Украйна

\title{
ТИПОЛОГІЧНА СТРУКТУРА Й ТАКСАЦІЙНІ ПОКАЗНИКИ РОБІНІЄВИХ ДЕРЕВОСТАНІВ У ЗАХИСНИХ ЛІСАХ ЛІСОГОСПОДАРСЬКОЇ ОБЛАСТІ БАЙРАЧНОГО СТЕПУ УКРАЇНИ
}

Проаналізовано особливості робінієвих деревостанів у лісах захисної функціональної категорії у лісогосподарській області Байрачного степу України. Наведено типологічну структуру деревостанів за участю робінії несправжньоакації (Robinia pseudoacacia L.). Досліджено розподіл площі робінієвих деревостанів за типами лісорослинних умов та типів лісу, групами віку, класами бонітету та відносними повнотами. За походженням робінієві деревостани захисних лісів лісогосподарської області Байрачного Степу України - штучні, створені лісовими культурами. Робінієві деревостани у досліджуваних захисних лісах високоповнотні. Найбільша частка площі (68,3 \%) деревостанів приурочена до відносної повноти 0,8. Вікова структура робінієвих деревостанів лісогосподарської області Байрачного степу України є незбалансованою, із значним переважанням перестиглих деревостанів - 74,9\%. Середній вік досліджуваних робінієвих деревостанів - 43 роки. Найбільший середній запас стовбурової деревини $\left(199 \mathrm{~m}^{3} \cdot \mathrm{ra}^{-1}\right)$ характерний для перестиглих робінієвих деревостанів віком $51-55$ років (XI клас віку). Встановлено, що найбільша частка робінієвих лісостанів Байрачного степу зосереджена у сугрудах - 67,6 \%. Частка грудових типів лісорослинних умов становить 20,5\% від площі. За ступенем зволоження грунтів робінія несправжньоакація, на теренах Байрачного степу, віддає перевагу сухим гігротопам, де зосереджено 92,1 \% площі робінієвих деревостанів. Встановлено, що у досліджуваному регіоні робінія несправжньоакація формує деревостани у двадцяти типах лісу, найпоширенішим з яких є галогенний варіант сухого сугруду. Найбільша площа робінієвих деревостанів у захисних лісах зайнята робінієвими деревостанами, які зростають за I класом бонітету (49,9 \%). Середній клас бонітету становить II,5.

Ключові слова: робінія несправжньоакація; типи лісу; Гельсінські критерії сталого розвитку лісового господарства; Дніпропетровське управління лісового та мисливського господарства.

\section{Вступ}

За умови антропогенної трансформації довкілля, особливої актуальності набуває пошук механізмів відновлення порушених природних та створення збалансованих штучних лісів задля нівелювання деградації земель. Лісова меліорація є одним з основних управлінських підходів до вирішення проблем, спричинених вітровою та водною ерозією грунтів, інтенсифікація яких спостерігається останнім часом, як наслідок змін клімату на глобальному і локальному рівнях.

Робінія несправжньоакація (Robinia pseudoacacia L.) - один з найпоширеніших деревних видів, за площею іiі штучні деревостани займають друге місце у світі, після насаджень тополь [20]. За оцінками G. Li et al. [8], площа робінієвих плантацій за межами ії природного ареалу становить понад 30 тис. км² у 35 країнах Європи, Азії, Південної Америки, Африки, Австралії та Нової Зеландії.

Робінієві деревостани у степовій зоні України є досить поширені: вони представлені у більшості типів ландшафтів, які виділив О. Л. Бельгард [1] - плакорах, apeнах та заплавах. Робінія несправжньоакація, як ін- тродукований, швидкорослий, технічно цінний вид, займає важливе місце у лісовому господарстві багатьох європейських країн $[15,19]$. В Україні використання робінії, як серевовищетвірного деревного виду, має давню історію. В Україні культури робінії створювали впродовж останніх ста років. За даними Н. А. Лохматова та Г. Б. Гладуна [12], вперше їх було закладено у степових лісництвах у 1860-1880 pp., у 30-ті роки ХХ ст. посаджено численні полезахисні смуги.

Серед робінієвих деревостанів виділяють три історично складені лісівничі групи [12]:

I група - деревостани першого і другого вегетативних поколінь, похідні від насіннєвих, які було закладено у 1860-1880 pp.

II група - яружно-балкові та схилові протиерозійні деревостани, які створені у 30 -х роках XX ст. Їхнє походження здебільшого насіннєве, мішане (насіннєве + вегетативне) або вегетативне, з парості першої генерації й кореневої парості.

III група - деревостани, створені у 1950-1990 рр., вздовж водосховищ, по берегах річок, прибалкових і придолинних схилах, яружно-балкових системах.

Робінія несправжньоакація - поліморфний вид. Ко-

Інформація про авторів:

Мурадян Лаура Вачаганівна, аспірант, кафедра екології. Email: Imuradian@ukr.net

Ситник Світлана Анатоліївна, канд. біол. наук, доцент, докторант, кафедра таксації лісу та лісового менеджменту. Email: sytnyk.s.a@dsau.dp.ua; https://orcid.org/0000-0002-7646-6347

Цитування за ДСту: Мурадян Л. В., Ситник С. А. Типологічна структура й таксаційні показники робінієвих деревостанів у захисних лісах лісогосподарської області Байрачного степу України. Науковий вісник НлтУ України. 2020, т. 30, № 5. С. 36-41.

Citation APA: Muradyan, L. V., \& Sytnyk, S. A. (2020). Typological structure and valuation features of black locust stands in protective forests within the Ravine Steppe of Ukraine. Scientific Bulletin of UNFU, 30(5), 36-41. https://doi.org/10.36930/40300506 
ханий С. Г. [7] виділив морфологічні форми цього виду зі значним лісокультурним потенціалом, перспективні для лісового господарства у природній зоні степу. Завдяки екологічній стратегії експлерента й швидкому накопиченню надземної фітомаси робінія несправжньоакація визнана одним з найперспективніших видів дерев для цілей лісової рекультивації порушених земель у степовій зоні $[5,13,17,21]$.

У лісогосподарській області Байрачного степу, за умови відсутності категорії експлуатаційних лісів, лісостани насамперед виконують екологічні функції. Одним із головних завдань державних лісогосподарських підприємств регіону дослідження є розвиток кліматорегулятивних, рекреаційних та, найголовніше, захисних властивостей штучних лісових насаджень. Ліси мають зменшувати негативні наслідки природних явищ, захищати грунти від ерозії та сприяти регулюванню стоку поверхневих вод. У площині захисного лісорозведення програмою "Ліси України" до 2015 р. на території Дніпропетровської області передбачалося створення нових лісових насаджень на 32,3 тис. га, проте реалізацію програми здійснено не було [15].

Деревостани робінії несправжньоакації у лісах, підпорядкованих Державному агентству лісових ресурсів України на території Дніпропетровської області, мають таку представленість за категоріями: ліси природоохоронного, наукового та історико-культурного призначення - 1831,1 га (18,8 \% від площі лісів зазначеної категоpiï), рекреаційно-оздоровчі ліси - 7173,5 га (22,9 \% площі рекреаційно-оздоровчих лісів); захисні ліси 8679,1 га (35,2 \% площі захисних лісів),

Вибір деревостанів робінії несправжньоакації для дослідження зумовлений значною площею на землях Держлісфонду Дніпропетровської області - 17,7 тис. га (27,6 \% від площі ділянок вкритих лісовою рослинністю), переважанням у захисних лісах регіону дослідження та значним меліоративним потенціал для попередження та нівелювання ерозії грунтів.

Об'єкт дослідження - типологічна структура й таксаційні показники захисних лісів за участю робінії несправжньоакації.

Предмет дослідження - методи і засоби визначення типологічної структури і таксаційних показників захисних лісів на території Держлісфонду лісогосподарської області Байрачного степу України за участю робінії несправжньоакації.

Мета роботи - проаналізувати особливості типологічної структури та основних таксаційних показників робінієвих деревостанів у Байрачному степу України.

Для досягнення зазначеної мети визначено такі основні завдання дослідження:

- проаналізувати вікову, повнотну та бонітетну структури робінієвих деревостанів;

- розробити математичну модель розрахунку середнього запасу стовбурової деревини залежно від віку деревостану;

- визначити типи лісорослинних умов та типи лісу робінієвих лісостанів у регіоні дослідження.

Наукова новизна отриманих результатів дослідження - вперше для умов лісогосподарської області Байрачного степу України проаналізовано структуру лісостанів за участю робінії несправжньоакації в розрізі їх складу, типів лісу, відносної повноти, віку, бонітету.

Практична значущість результатів дослідження отримані результати дають змогу забезпечити систему менеджменту у захисних лісах степової зони.
Аналіз останніх досліджень та публікацій. Масштабні дослідження меліоративних, морфологічних, фізіологічних, екологічних, стехіометричних властивостей Robinia pseudoacacia здійснюють у Центральному Китаї на Плато Лоес - 640 тис. км² площі суходолу із масштабною ерозією, яку виявляють у великій кількості балок та ярів 3 середньою довжиною 5 км· $\left(\mathrm{\kappa м}^{2}\right)^{-1}[2]$. Результатами численних досліджень аллохтонних лісотвірних видів у еродованому Плато Лоес Robinia pseudoacacia визнана найперспективнішим видом [9, 10, 11]. Особливо цікавим $є$ аналіз результатів багатовекторного вивчення робінієвих насаджень китайськими вченими 3 огляду на подібність фізико-географічних i погодно-кліматичних умов Плато Лоес і природної зони степу України - лімітуючих абіотичних чинників для функціонування деревних рослин, зокрема суми та річного розподілу опадів, дефіциту грунтової й атмосферної вологи.

Ліси степової зони України, за участю робінієвих деревостанів, досліджували вітчизняні вчені у різноманітних лісівничих, лісокультурних, екологічних та меліоративних аспектах. Особливості функціонування цього лісотвірного виду у степових ландшафтах досліджено у роботах Н. А. Лохматова і Г. Б. Гладуна [12]. Меліоративний потенціал робінії під час рекультивації трансформованих ландшафтів у степовій зоні доведено у роботах V. M. Zverkovskyy [21], А. Н. Масюка [14], Ю. І. Грицана [6], В. В. Танюкевич і М. А. Заприводи [18].

Проте у лісогосподарській області Байрачного степу України дослідження лісівничих і таксаційних особливостей модальних деревостанів робінії несправжньоакації $є$ актуальними, для з'ясування відповідності певним індикаторам Гельсінських критеріїв сталого управління лісами, задля розроблення ефективної доцільної системи менеджменту та функціонування високопродуктивних, біологічно стійких робінієвих деревостанів у захисних лісах природної зони степу. Результати досліджень мають слугувати базисом визначення лісогосподарських заходів, спрямованих на економічно доцільне й екологічно безпечне ведення лісового господарства.

Матеріали та методи дослідження. У практику ведення лісового господарства у степових лісах мають бути імплементовані принципи сталого розвитку лісів. Оцінювання типологічної структури і лісотаксаційних показників модальних робінієвих деревостанів здійснено за V Гельсінським критерієм "Підтримання та розвиток захисних функиій лісів у лісовому господарстві, особливо протиерозійних та водозахисних". Серед індикаторів цього критерію - площа лісів зі схильними до ерозії грунтами; площа захисних лісів і таксаційні показники модальних деревостанів.

Для аналізу таксаційних показників робінієвих деревостанів використано матеріали базового лісовпорядкування державного підприємства "Верхньодніпровське лісове господарство" (2014 р.), яке підпорядковано Дніпропетровському обласному управлінню лісового та мисливського господарства й у лісовому фонді якого, переважно, зосереджені захисні ліси за участю робінії несправжньоакації. Загалом проаналізовано лісівничі та таксаційні дані лісових насаджень за участю робінії несправжньоакації із 1902 таксаційних виділів загальною площею 7095,1 га. За класифікацією С. А. Генсірука [4], захисні ліси за участю робінії несправжньоакації ДП 
"Верхньодніпровське лісове господарство" зростають на території лісогосподарської області Байрачного Степу України, що й окреслює регіон дослідження. Вихідними даними для розподілу площі захисних лісів за групами віку й лісотвірних видів слугували матеріали галузевої звітності Дніпропетровського обласного управління лісового та мисливського господарства і державна статистична інформація (http://www.dneprstat. gov.ua).

\section{Результати дослідження та їх обговорення}

Більшість площі лісів (24,6 тис. га, або 37,4 \% від площі ділянок, вкритих лісовою рослинністю державних лісогосподарських підприємств), підпорядкованих Державному агентству лісових ресурсів України у Дніпропетровській області, віднесено до категорії захисні ліси, які у регіоні дослідження запобігають ерозії грунту та затримують твердий стік. Дані вікової структури деревостанів захисних лісів за групами лісотвірних видів наведено у табл. 1.

Три чверті площі ділянок, вкритих лісовою рослинністю, у захисних лісах знаходяться під деревостанами твердолистяних видів, переважно дубом високостовбурним та робінією несправжньоакацією.
Робінієві деревостани у регіоні дослідження мають штучне походження. За складом робінієві деревостани $\epsilon$ чистими (6466,0 га, або 91,1\%), мішані деревостани займають площу 629,1 га $(8,9 \%)$. Зростання цього лісотвірного виду відбувається разом із дубом звичайним, ясенами зеленим і звичайним, тополями білою та чорною.

Вік - це основний показник під час планування та здійснення більшості лісогосподарських заходів, тому важливим $\epsilon$ аналіз вікової структури деревостанів (табл. 2). Аналіз вікової структури досліджуваних робінієвих демонструє нерівномірний розподіл площі, зайнятої деревостанами різних груп віку. Діапазон віку - 5-95 років. Для вікової структури модальних деревостанів робінії несправжньоакації характерне істотне переважання перестиглих деревостанів, які займають 74,9\% (5319,9 га) від загальної площі деревостанів цього виду. Найменшу частку площі займають молодняки (деревостани віком до 10 років), яка становить $3,0 \%$ від загальної площі робінієвих деревостанів, пристиглі - 1,3\%, середньовікові та стиглі - 2,9 і 17,8 \% відповідно. Середній вік робінієвих деревостанів лісогосподарської області Байрачного степу - 43 роки.

Табл. 1. Площа ділянок, вкритих лісовою рослинністю у захисних лісах, га

\begin{tabular}{|c|c|c|c|c|c|c|}
\hline \multirow{2}{*}{$\begin{array}{c}\text { Група } \\
\text { лісотвірних видів }\end{array}$} & \multicolumn{6}{|c|}{ Група віку } \\
\hline & молодняки & середньовікові & пристиглі & стиглі & перестиглі & всього \\
\hline Хвойні & 1702,3 & 3208,2 & 6,5 & - & - & 4917 \\
\hline Твердолистяні & 1628,1 & 5952,2 & 1333,0 & 3347,4 & 6562,4 & 18823,1 \\
\hline М'яколистяні & 0,6 & 80,9 & 45,7 & 87,1 & 103,9 & 318,2 \\
\hline Інші деревні види & 62,1 & 182,4 & 45,3 & 35,9 & 32,1 & 357,8 \\
\hline Чагарники & 17,8 & 32,3 & 34,4 & 93,7 & 18,1 & 196,3 \\
\hline Загалом & 3410,9 & 9456,0 & 1464,9 & 3564,1 & 6716,5 & 24612,4 \\
\hline
\end{tabular}

Табл. 2. Вікова структура деревостанів робінії несправжньоакації

\begin{tabular}{|c|c|c|c|c|c|c|}
\hline \multirow{2}{*}{ Показник } & \multirow{2}{*}{ Всього } & \multicolumn{4}{|c|}{ Група віку } \\
\cline { 3 - 6 } & & молодняки & середньовікові & пристиглі & стиглі & перестиглі \\
\hline Площа, га & 7095,1 & 213,5 & 207,7 & 90,8 & 1263,2 & 5319,9 \\
\hline Запас, тис. $\mathrm{m}^{3}$ & 1248,6 & 3,9 & 7,2 & 3,4 & 211,4 & 1017,7 \\
\hline Середній запас, $\mathrm{m}^{3} \cdot \mathrm{ra}^{-1}$ & 175 & 18 & 34 & 92 & 167 \\
\hline
\end{tabular}

Найменша частка запасу стовбурової деревини деревостанів зосереджена у віковій групі молодняків $0,3 \%$ загального запасу, у середньовікових деревостанах $-0,6 \%$; пристиглих $-0,7 \%$; стиглих $-16,9 \%$. Левова частка запасу стовбурової деревини зосереджена у деревостанах перестиглої групи віку - 81,5 \%.

Наявні вікова структура деревостанів та розподіл запасів стовбурової деревини робінії за групами віку не $є$ оптимальними та можуть бути наслідком незадовільного менеджменту захисними лісами у регіоні дослідження.

На рис. 1 графічно зображено залежність середнього запасу стовбурової деревини від віку деревостану. Клас віку робінії несправжньоакації, як швидкоростучого деревного лісоутвірного виду, становить 5 років. За величиною показника достовірності апроксимації залежності між середнім стовбуровим запасом та віком розроблено математичну модель, яку описує поліноміальна функція (рис. 1). Найбільший середній запас деревини $\left(199 \mathrm{~m}^{3} \cdot \mathrm{ra}^{-1}\right)$ характерний для перестиглих робінієвих деревостанів віком 51-55 років (XI клас віку), а найменший серед перестиглої групи - дерева VII класу віку (31-35 років) $-141 \mathrm{~m}^{3} \cdot$ га $^{-1}$.

У регіоні дослідження за площею домінують робінієві деревостани з відносною повнотою 0,8-4843,8 га, або 68,3\% (рис. 2). Низькоповнотні деревостани майже відсутні, частка деревостанів 3 показником відносної повноти 0,6 і нижче становить усього 1,4 \% від площі досліджуваних деревостанів.

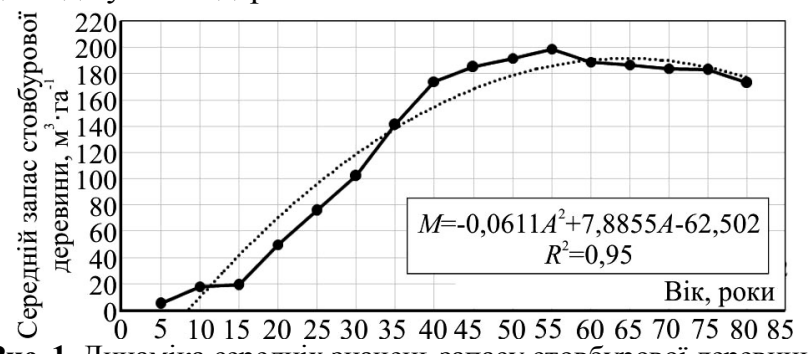

Рис. 1. Динаміка середніх значень запасу стовбурової деревини робінієвих деревостанів

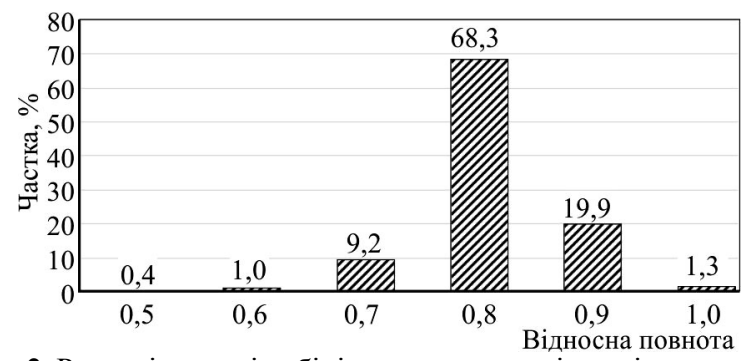

Рис. 2. Розподіл площі робінієвих деревостанів за відносними повнотами деревостанів

Велика площа та різноманітність типів ландшафтів степової зони України та лісогосподарської області Байрачного степу України зокрема, зумовлюють широкий 
спектр умов місцезростань та їхніх мікрокліматичних характеристик. Провідними чинниками створення і подальшої динаміки штучних робінієвих деревостанів $є$ лісорослинні умови. Оцінювання типів лісорослинних умов дає змогу не тільки оцінити потенціал різних типів і видів грунтів, але й визначити оптимальний для них склад лісотвірних видів і способи вирощування лісів різного цільового призначення.

Згідно з типологією Алексєєва-Погребняка, робінієві деревостани у захисних лісах регіону дослідження функціонують у вісьмох едафотопах $-\mathrm{B}_{0}-\mathrm{B}_{2} ; \mathrm{C}_{0}-\mathrm{C}_{2}, \mathrm{D}_{1}-\mathrm{D}_{3}$ (табл. 3). Найбільша площа досліджуваних деревостанів зосереджена у сугрудах - 4804,6 га (67,6 \% від загальної площі досліджуваних деревостанів). У грудах функціонує майже третина деревостанів - 2246,2 га $(31,7 \%)$. На незначній площі досліджуваний вид формує деревостани у бідних грунтових умовах суборів - 44,3 га $(0,7 \%)$. Зазначимо відсутність робінієвих деревостанів захисних лісів у найбідніших умовах борів. Переважають сухі грунти, у яких на 6543,9 га (92,1%) площі робінієві деревостани зазнають дії лімітуючого екологічного абіотичного чинника - дефіциту грунтової вологи.

Табл. 3. Розподіл площі робінісвих деревостанів захисних лісів за типами лісорослинних умов

\begin{tabular}{|c|c|c|c|c|c|c|c|c|c|c|}
\hline \multirow{3}{*}{ Гігротоп } & \multicolumn{8}{|c|}{ Трофотоп } & \multicolumn{2}{|c|}{ Разом для гігротопів } \\
\hline & \multicolumn{2}{|c|}{$A-$ бip } & \multicolumn{2}{|c|}{ В - субір } & \multicolumn{2}{|c|}{ C- сугруд } & \multicolumn{2}{|c|}{$\mathrm{D}$ - груд } & \multirow{2}{*}{ га } & \multirow{2}{*}{$\%$} \\
\hline & га & $\%$ & га & $\%$ & га & $\%$ & га & $\%$ & & \\
\hline 0 -дуже сухі & - & - & - & - & 153,4 & 2,2 & - & - & 153,4 & 2,2 \\
\hline $1-$ cyxi & - & - & 33,7 & 0,5 & 4519,8 & 63,5 & 1990,4 & 28,1 & 6543,9 & 92,1 \\
\hline $2-$ свіжі & - & - & 10,6 & 0,2 & 131,4 & 1,9 & 251,2 & 3,5 & 393,2 & 5,6 \\
\hline 3 -вологі & - & - & - & - & - & - & 4,6 & 0,1 & 4,6 & 0,1 \\
\hline 4 - сирі & - & - & - & - & - & - & - & - & - & - \\
\hline 5-мокрі & - & $\begin{array}{llll}- & \\
\end{array}$ & - & - & - & - & - & - & $\begin{array}{llll}- & \\
\end{array}$ & - \\
\hline Разом для трофотопів & - & - & 44,3 & 0,7 & 4804,6 & 67,6 & 2246,2 & 31,7 & 7095,1 & 100,0 \\
\hline
\end{tabular}

Згідно з проаналізованими вихідними даними, робінієві деревостани захисних лісів зростають у двадцяти типах лісу (табл. 4). Половина площі (5668,8 га або $50,5 \%$ припадає на деревостани, які зростають у галогенному варіанті сухого сугруду, де зазнають впливу надлишкового вмісту солей у грунті. Значно поширена суха бересто-пакленова діброва. В умовах свіжого гігротопу представлені вісім типів лісу, загальна площа робінієвих деревостанів у згаданих типах лісу виявилась незначною - 393,2,2 га (5,5 \%).

Табл. 4. Розподіл площі робінісвих деревостанів за типами лісу

\begin{tabular}{|c|c|c|}
\hline & Тип лісу & Площа, \\
\hline $\mathrm{B}_{1}$-дC & Сухий дубово-сосновий субір & 19,2 \\
\hline $\mathrm{B}_{1}^{\mathrm{h}}$ & Сухий субір галогенний варіант & 14,5 \\
\hline $\mathrm{B}_{2}$-дC & Свіжий дубово-сосновий субір & 6,4 \\
\hline $\mathrm{B}_{2}^{\mathrm{h}}$ & Свіжий субір галогенний варіант & 4,2 \\
\hline $\mathrm{C}_{0}^{\mathrm{h}}$ & Дуже сухий сугруд галогенний варіант & 150,3 \\
\hline $\mathrm{C}_{0}$-клД & Дуже суха пакленова судіброва & 3,1 \\
\hline $\mathrm{C}_{1}^{\mathrm{h}}$ & Сухий сугруд галогенний варіант & 3581,0 \\
\hline $\mathrm{C}_{1}$-клД & Суха пакленова судіброва & 938,8 \\
\hline $\mathrm{C}_{2}^{\mathrm{h}}$ & Свіжий сугруд галогенний варіант & 3,3 \\
\hline $\mathrm{C}_{2}-\mathrm{T}^{3}$ & Свіжий заплавний тополевий сугруд & 74,4 \\
\hline $\mathrm{C}_{2}-$-брд ${ }^{3}$ & Свіжа заплавна берестова судіброва & 49,8 \\
\hline $\mathrm{C}_{2}$-КлД & Свіжа пакленова судіброва & 3,9 \\
\hline $\mathrm{D}_{1}^{\mathrm{h}}$ & Сухий груд галогенний варіант & 343,9 \\
\hline $\mathrm{D}_{1}$-бр-клД & Суха бересто-пакленова діброва & 1564,7 \\
\hline $\mathrm{D}_{2}$-бр-клд $Д^{\mathrm{h}}$ & $\begin{array}{l}\text { Суха бересто-пакленова діброва гало- } \\
\text { генний варіант }\end{array}$ & 81,8 \\
\hline $\mathrm{D}_{2}$-бр-клД & Свіжа бересто-пакленова діброва & 212,4 \\
\hline $\mathrm{D}_{3}$-бр-клд ${ }^{3}$ & $\begin{array}{l}\text { Свіжа заплавна бересто-пакленова діб- } \\
\text { рова }\end{array}$ & 0,4 \\
\hline $\mathrm{D}_{2}{ }^{\mathrm{h}}$ & Свіжий груд галогенний варіант & 36,3 \\
\hline $\mathrm{D}_{3}$-бр-кл $Д^{3 \mathrm{~h}}$ & $\begin{array}{l}\text { Свіжа заплавна бересто-пакленова діб- } \\
\text { рова галогенний варіант }\end{array}$ & 2,1 \\
\hline $\mathrm{D}_{3}$-бр-кпД & $\begin{array}{l}\text { Волога заплавна бересто-пакленова діб- } \\
\text { рова }\end{array}$ & 4,6 \\
\hline & Всього & 7095,1 \\
\hline
\end{tabular}

Актуальним $\epsilon$ виявлення закономірностей формування і функціонування деревостанів 3 максимальною продуктивністю та оцінювання впливу абіотичних чинників едафотопів на формування стовбурової деревини.
Аналіз даних, наведених на рис. 3, свідчить, що за запасом стовбурової деревини перестиглі деревостани переважають в усіх трофотопах, займаючи від 80,0 \% у грудах до 95,0 \% у суборах.

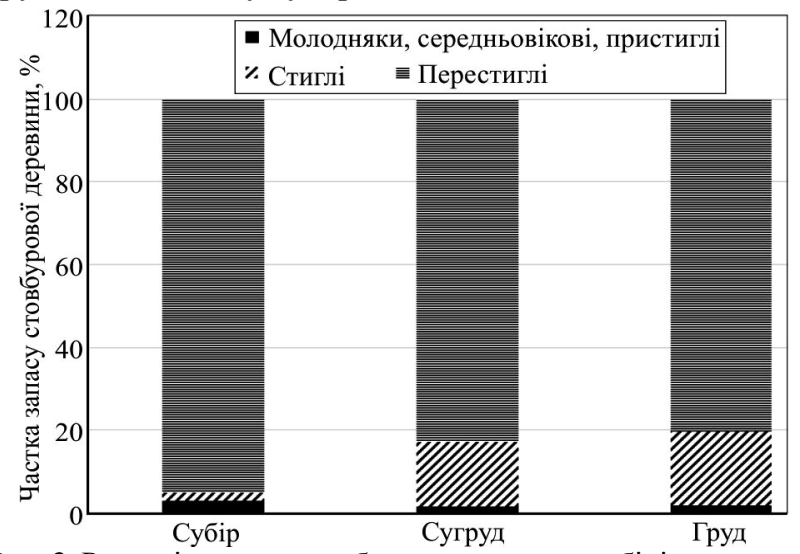

Рис. 3. Розподіл запасу стовбурової деревини робінієвих деревостанів захисних лісів за трофотопами та групами віку, \%

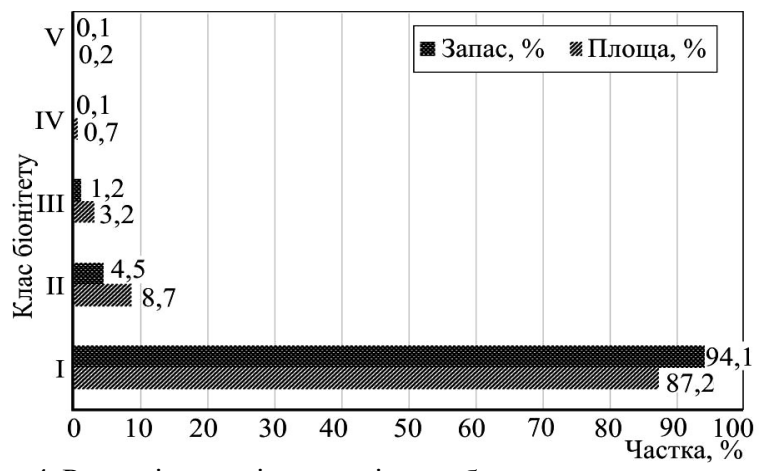

Рис. 4. Розподіл площі та запасів стовбурової деревини у деревостанах робінії несправжньоакації за класами бонітету, \%

Основну частину площі - 6263,4 га - займають деревостани робінії, які зростають за І класом бонітету (рис. 4). Деревостани робінії, які зростають за I класом бонітету, функціонують переважно в умовах галогенного варіанта сухого сугрудку (3150,4 га, або 50,3 \% від площі, зайнятої деревостанами досліджуваного виду, які зростають за I класом бонітету). Середній клас бонітету робінієвих деревостанів становить II,5. 
Значна представленість високобонітетних деревостанів та дуже незначна частка низькобонітетних (V клас) демонструють відповідність досліджуваного виду лісорослинним умовам лісогосподарської області Байрачного степу України.

\section{Висновки}

1. У захисних лісах лісогосподарській області Байрачного степу робінієві деревостани мають штучне походження. За складом переважають чисті деревостани, мішані займають площу 629,1 га (8,9\%). Зростання робінії відбувається разом із дубом звичайним, ясенами зеленим і звичайним, тополями білою та чорною.

2. Вікова структура робінієвих деревостанів лісогосподарської області Байрачного степу України є незбалансованою, із значним переважанням перестиглих деревостанів - 74,9\%. Молодняки та середньовікові деревостани загалом займають до $6,0 \%$ площі робінієвих деревостанів захисних лісів. Середній вік робінієвих деревостанів - 43 роки.

3. Найбільший середній запас деревини (199 м3·ra-1) характерний для перестиглих робінієвих деревостанів віком 51-55 років (XI клас віку). Для практичного застосування запропоновано математичну модель розрахунку середнього запасу стовбурової деревини залежно від віку деревостану.

4. Робінієві деревостани в умовах Байрачного степу функціонують у трьох трофотопах: суборах, сугрудах і грудах. Найбільша частка $(67,6$ \%, або 4804,6 га) зосереджена у сугрудових умовах. За ступенем зволоження грунтів робінія несправжньоакація у захисних лісах найбільшого поширення набула у сухих гігротопах. Частка деревостанів у цих умовах становить 92,1 \% від площі досліджуваних робінієвих деревостанів.

5. Найпоширенішими типами лісу є галогенний варіант сухого сугруду $(\mathrm{C} 1 \mathrm{~h})-3581,0$ га або 51,9\% та суха бересто-пакленова діброва (D1-бр-клД) - 1564,7 га або $22,1 \%$.

6. Більшість робінієвих деревостанів зростає за I класом бонітету (49,9\%). Середній бонітет становить II,5. Деревостани робінії, які зростають за I класом бонітету, функціонують переважно в умовах галогенного варіанта сухого сугруду.

7. Робінієві деревостани у Байрачному степу, переважно, є високоповнотними. Найбільша частка (68,3 \%) має відносну повноту 0,8. Частка низькоповнотних деревостанів загалом становить 1,4 \% від площі досліджуваних деревостанів.

\section{References}

1. Belgard, A. L. (1971). Stepnoe lesorazvedenie. Moscow: Lesnaya promyishlennost, 321 p. [In Russian].

2. Chen, L., Deng, Q., Yuan, Z., Mu, X., \& Kallenbach, R. (2018). Age-related $\mathrm{C}: \mathrm{N}: \mathrm{P}$ stoichiometry in two plantation forests in the Loess Plateau of China. Ecological Engineering, 120, 14-22. https://doi.org/10.1016/j.ecoleng.2018.05.021

3. Hanover, J. W., Werner, D., \& Mólle, P. (1990). Physiological genetics of black locust (Robinia psendoacacia L.): a model multipurpose tree species. Fast Growing Trees and Nitrogen Fixing Trees. New York, Stuttgart: Gustav Fischer Verlag.

4. Hensiruk, S. A. (2002). Lisy Ukrainy. Lviv: Ukrainski tekhnolohii, 496 p. [In Ukrainian].

5. Horodecki, P., \& Jagodziński, A. (2017). Tree species effects on litter decomposition in pure stands on afforested post-mining sites. Forest Ecology and Management, 406, 1-11. https://doi.org/10.1016/j.foreco.2017.09.059
6. Hrytsan, Yu. I. (2000). Ekolohichni osnovy peretvoriuiuchoho vplyvu lisovoi roslynnosti na stepove seredovyshche. Dnipropetrovsk: DNU, 300 p. [In Ukrainian].

7. Kohanyiy, S. G. (2010). Osobennosti machtovoy formyi beloy akatsii. Promislova botanIka: stan ta perspektivi rozvitku, 257258. [In Ukrainian].

8. Li, G., Zhang, X., Huang, J., Wen, Z., \& Du, S. (2018). Afforestation and climatic niche dynamics of black locust (Robinia pseudoacacia). Forest Ecology and Management, 407, 184-190. https://doi.org/10.1016/j.foreco.2017.10.019

9. Liang, H., Xue, Y., Li, Z., Wang, S., Wu, X., Gao, G., Liu, G., \& Fu, B. (2018). Soil moisture decline following the plantation of Robinia pseudoacacia forests: Evidence from the Loess Plateau. Forest Ecology and Management, 412, 62-69. https://doi.org/10.1016/j.foreco.2018.01.041

10. Liu, D., Huang, Y., Sun, H., \& An, S. (2018). The restoration age of Robinia pseudoacacia plantation impacts soil microbial biomass and microbial community structure in the Loess Plateau. Catena, 165, https://doi.org/10.1016/j.catena.2018.02.001

192-200.

11. Liu, J., Ngoc, V., Shen, Z., Dang, P., Zhu, H., Zhao, F., \& Zhao, Z. (2018). Response of the rhizosphere microbial community to fine root and soil parameters following Robinia pseudoacacia L. afforestation. Applied Soil Ecology, 132, 11-19. https://doi.org/10.1016/j.apsoil.2018.08.004

12. Lohmatov, N. A., \& Gladun, G. B. (2004). Lesnyie melioratsii v Ukraine: istoriya, sostoyanie, perspektivyi. Harkov: Novoe slovo, 256 p. [In Russian].

13. Mantovani, D., Veste, M., \& Freese, D. (2014). Black locust (Robinia pseudoacacia L.) ecophysiological and morphological adaptations to drought and their consequence on biomass production and water-use efficiency. New Zealand Journal of Forest Science, 44, 29-38. https://doi.org/10.1186/s40490-014-0029-0

14. Masyuk, A. N. (2006). Analiz pervichnoy produktsii nasazhdeniy robinii lozhnoakatsii na rekultivirovannyih zemlyah stepnogo Pridneprovya. Scientific Bulletin of the Dnipro National University, 3(1), 118-125. [In Russian].

15. Polozhennia. (2011). Osnovni polozhennia orhanizatsii i rozvytku lisovoho hospodarstva Dnipropetrovskoi oblasti. Irpin: Ukrderzhlisproekt, 132 p. [In Ukrainian].

16. Radtke, A., Ambrab, S., Zerbe, S., Tonon, G., Fontana, V., \& Ammer, C. (2013). Traditional coppice forest management drives the invasion of Ailanthus altissima and Robinia pseudoacacia into deciduous forests. Forest Ecology and Management, 291, 308317. https://doi.org/10.1016/j.foreco.2012.11.022

17. Sun, H., Koal, P., Gerl, G., Schroll, R., Joergensen, R., \& Munch, J. (2017). Response of water extractable organic matter and its fluorescence fractions to organic farming and tree species in poplar and robinia-based alley cropping agroforestry systems. Geoderma, 290 ,

83-90. https://doi.org/10.1016/j.geoderma.2016.12.014

18. Tanyukevich, V. V., \& Zaprivoda, M. A. (2014). Opyit primeneniya robinii lozhnoakatsievoy (Robinia pseudoacacia L.) v rekultivatsii terrikonikov Donetskogo kryazha. Scientific Bulletin of the RNII reclamation problems, 1(13), 108-111. [In Russian].

19. Vítková, M., Pergl, J., \& Sádlo, J. (2016). Black locust (Robinia pseudoacacia $\mathrm{L}$.): from global ecology to local management - a case study from the Czech Republic. In: Krumm, F., Vítková, L. (Eds.). Introduced Tree Species in European Forests: Opportunities and Challenges. Freiburg: European Forest Institute.

20. Wojda, T., Klisz, M., Jastrzebowski, A., Mionskowski, M., SzypBorowska, I., \& Szczygiel, K. (2015). The geographical distribution of the black locust (Robinia pseudoacacia L.) in Poland and its role on non-forest land. Papers on Global Change IGBP, 22(1), 101-113.

21. Zverkovskyy, V. M., Sytnyk, S. A., Lovynska, V. M., Kharytonov, M. M., Lakyda, I. P., Mykolenko, S. Yu., Pardini, G., Margui, E., \& Gispert, M. (2018). Remediation potential of forest forming tree species within northern Steppe reclamation stands. Ekológia (Bratislava), 37(1), 69-81. https://doi.org/10.2478/eko$\underline{2018-0007}$ 
${ }^{I}$ Dnipro State Agrarian and Economic University, Dnipro, Ukraine

${ }^{2}$ National University of Life and Environmental Sciences of Ukraine, Kyiv, Ukraine

\section{TYPOLOGICAL STRUCTURE AND VALUATION FEATURES OF BLACK LOCUST STANDS IN PROTECTIVE FORESTS WITHIN THE RAVINE STEPPE OF UKRAINE}

Forest reclamation is one of the main management approaches to solving the problems caused by wind and water erosion of soils, the intensification of which has been observed recently as a result of climate change at the global and local levels. Due to the ecological strategy of the expert and the rapid accumulation of aboveground phytomass, Black locust (Robinia pseudoacacia L.) is recognized as one of the most promising tree species for the purposes of forest reclamation of disturbed lands in the Steppe zone in Ukraine. Materials of basic forest management of the Verchniodniprovsk Forestry SOE (2014) were used to analyze forest typological structure and the valuation features of the Black locust forest fund. Black locust stands of protective forests of the forestry region of the Ravine Steppe of Ukraine are revealed to be artificial by origin, created by growing forest plantations. The age structure of the Black locust stands in the forestry region is unbalanced, with a significant predominance of overmature stands $-74.9 \%$. The average age of the studied Black locust stands is 43 years. The largest average stock of trunk wood $\left(199 \mathrm{~m}^{3} \cdot \mathrm{ha}^{-1}\right)$ is characterized by overmature Black locust stands aged 51-55 years (XI class of age). It is established that the largest share of Black locust stands of the Ravine Steppe is concentrated in the fairly fertile soil type conditions $-67.6 \%$. Fertile soil types of forest vegetation conditions make up $20.5 \%$ of the area of the Black locust stands. According to the degree of soil moisture of the investigated stands within the territory of the Ravine Steppe forestry region, prefers dry conditions, where $92.1 \%$ of the Black locust forest stands in the region are concentrated. It is found that Black locust participates in the formation of twenty forest types in the studied region, the most common of which is the halogen variant of dry fairly fertile soil type. The largest area of studied stands in protective forests is occupied by Robinia stands, which grow in the first class of stand quality (94.1\%). The average class quality is II.5. Black locust stands in the protective forests within Riparian Steppe forestry region are mostly high-density stand stocking. The largest share $(68.3 \%)$ is timed to the fullness of 0.8. Significant representation of high quality stand demonstrates the similarity of the Black locust stands to the forest site conditions within protective forests of Ravine Steppe of Ukraine.

Keywords: Black locust; forest types; forest biometric structure; Helsinki criteria of sustainable forestry development; Dnipropetrovsk Department of Forestry and Hunting. 